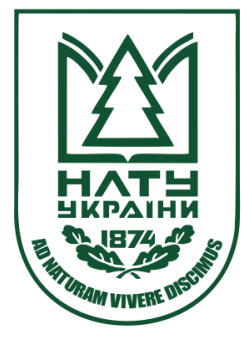

Науковий вісник НЛТУ України

Scientific Bulletin of UNFU

http://nv.nltu.edu.ua

https://doi.org/10.15421/40270801

Article received 21.10.2017 p.

Article accepted 24.11.2017 p.

UDC $630 * 91$
ISSN 1994-7836 (print)

ISSN 2519-2477 (online)

$@ \bowtie$ Correspondence author

I. P. Soloviy

soloviy@yahoo.co.uk

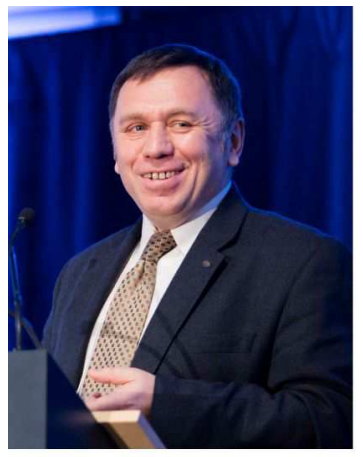

Ihor Soloviy,

Dr. Hab., Professor,

Email: ihor.soloviy@nltu.edu.ua

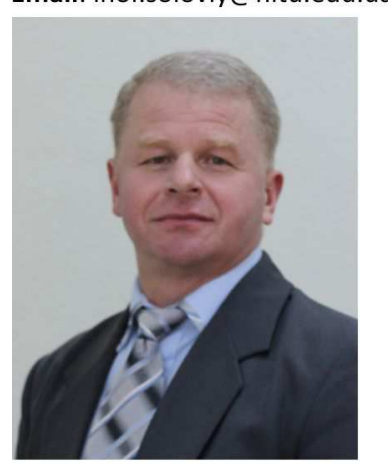

Ion Dubovich,

PhD, Associate Professor,

Email: iondubovich@nltu.edu.ua

\title{
IUFRO ANNIVERSARY CONGRESS: RESULTS AND PROSPECTS FOR COOPERATION IN THE FIELD OF FORESTRY SCIENCE
}

Introduction. Forests play an important place in sustaining life on Earth. Therefore, forest-related research is especially valuable for a society as the basis for sustainable development at a global level. It has a decisive role in deepening public understanding and finding a practical solution to a wide range of environmental, economic and social issues pertaining to forests.

Therefore, the collaboration between forestry researchers, which increases the efficiency of their research, is extremely important and relevant. To ensure sustainable development, scientists must synthesize information on biological, economic and social conditions within and around forest areas. This is achieved by taking into account the temporal and spatial limitations present in the nature of scientific research. It is also important to remember that local con- ditions regarding forest ecosystem research plays a role in understanding underlying factors.

Today, the International Union of Forest Research Organizations (IUFRO) is the leading global network of forestry organizations and it's the only international organization that comprehensively explores forests and forestry, covering also many related disciplines.

The mission of the IUFRO is to advance knowledge sharing, mastery of excellence, the development of disciplinary and interdisciplinary scientifically-based forest-related decisions in favor of conserving and restoring forest ecosystems and ensuring people's well-being throughout the world. IUFRO promotes collaboration in the field of research and scientific knowledge dissemination among policymakers, environmental and economic decision-makers.

Цитування за ДСтУ: Soloviy I. P., Dubovych I.A. IUFRO Anniversary Congress: Results and Prospects for cooperation in the Field of Forestry Science. Науковий вісник НЛтУ України. 2017. Вип. 27(8). С. 16-20.

Citation APA: Soloviy, I. P., Dubovych, I. A. (2017). IUFRO Anniversary Congress: Results and Prospects for cooperation in the Field of Forestry Science. Scientific Bulletin of UNFU, 27(8), 16-20. https://doi.org/10.15421/40270801 
IUFRO also contributes to forest policy formulation and implementation towards sustainable forest management in all parts of the world. Its unique membership network brings together research organizations, universities and scholars who have joined it in the form of individual membership.

The purpose of the work is to highlight the activities of IUFRO which include: coordinating scientific research related to forests and forestry at the international level, and formulation and implementation of forest policy in accordance with the concept of sustainable forest management worldwide.

Results. IUFRO is one of the oldest international scientific organizations in the world. The idea of an organization of international cooperation in the field of forest research was first proposed in 1890 by Austrian forester Karl Böhmerle. Officially, IUFRO was founded on August 17, 1892 in Eberswalde (Germany). The co-founders were three members: the Association of German Forestry Experimental Stations and Experimental Stations in Austria and Switzerland.

However, it has rapidly become a major global organization that today represents more than 15,000 scientists in more than 600 member organizations in 126 countries. More than 700 researchers specializing in a wide range of scientific disciplines and research areas coordinate with IUFRO departments, research and working groups, and so-called Task Forces to solve the above tasks.

The thematic scope of the organization has no analogues and includes more than 250 scientific units. The exceptional features of IUFRO as a network organization are also well reflected in more than seventy events funded and conducted annually (Johann, 2017).

The fundamental vision of IUFRO includes the development of free and non-political cooperation in the field of forest research and has proved to be a powerful and sustainable guideline. It remains unchanged despite the radical changes that have taken place in the political arena and in the social system over the past decades. For example, two world wars temporarily interrupted the work of the IUFRO, but even they did not seriously threaten the functioning and development of the organization.

At the time of the establishment, a topic of discussion among forestry scientists was issues of seen peculiarities of trees growth and wood stocks, as well as technical methods of measuring the indicators that characterize them. Since then, the field of research related to forests has considerably expanded. Understanding the interdependence of technical measures and social change, as well as their interregional relevance, has become a priority for research.

Besides that, purely economic aspects of forestry have waned. It is inspired by the fact that scientists and politicians have become deeply aware of the interrelationships between the social, ecological and economic aspects of forestry. Also, the multifaceted (organizational, publishing, educational, etc.) activities of IUFRO led to the fact that among the modern forest researchers there was an understanding that renewable resources can be used only in a sustainable way. That is, the regeneration capacity of forests should be taken cautiously, and non-renewable resources should be consumed very sparingly.

In order to meet the needs of preserving forests, it is also necessary to meet the needs and those who lay the foundations for the protection, sustainable use and reproduction of forests - forest researchers. For example, it is important to create conditions that allow forest researchers to cooperate freely in order to maximize the organizational impact of such cooperation.

They should also have the right and opportunity to appoint experts in the context of this cooperation. In addition, once a specific research topic has given a clear result it should be widespread and find application in practice.

IUFRO is based on the recognition that research cooperation is important for the future of forests and people. Since its foundation, significant progress has been made in understanding the functions of forest ecosystems, the importance of multi-purpose forest resource use, and methods of sustainable non-exhaustive long-term forest management.

Current and future global trends, such as population growth, economic globalization and climate change, illegal logging, are creating new challenges for forests and people who depend on them. Solving these problems requires a more efficient and effective collaboration between the scientific disciplines and economic sectors. Therefore, the problems that led to the initiating of the IUFRO remain relevant today.

During the last 125 years, IUFRO has promoted international forestry research cooperation covering a full range of forest related issues. During this period, the organization has become a network with significant potential for achieving sustainable development goals set by the United Nations until 2030.

The current IUFRO Strategy addresses issues of importance for humanity such as access to food, drinking water, affordable energy, revenues and jobs, as well as ensuring sustainable development and greater resilience to the effects of climate change and natural hazards. IUFRO-participating institutions and individual researchers who work with IUFRO create a responsibility for those affiliated with organization to create and share knowledge. This knowledge generation and sharing provide scientifically sound solutions to current and future global challenges for the benefit of forests and people.

The IUFRO 125th Anniversary Congress, which gathered more than 2000 participants from all over the world, was held in Freiburg, Germany from 18-22 September 2017. This Congress was a unique opportunity to celebrate the achievements and role of IUFRO in providing a scientific basis for policy decisions at all levels, enhancing cooperation with stakeholders, and building bridges to other sectors such as water use, agriculture and energy.

The achievements of the IUFRO and political decisions were addressed in the introductory part of the Congress, moderated by the Chairman of the Organizing Committee Prof. Konstantin von Toefel, Director of the Institute for Forest Research, Baden-Württemberg, Freiburg (Germany).

At the opening ceremony were: Michael Wingfield, president of IUFRO, Pretoria (South Africa), Peter Hauck, Minister for Rural Affairs and Consumer Protection, BadenWurttemberg, Stuttgart (Germany), Philippe Richter, President Gregor Schirmbek, President of the German Forestry Council, Berlin (Germany), Mark Palachi, Director of the European Forestry Institute, Joensuu (Finland), Greater Eastern Region, Strasbourg, France.

In particular, the President of IUFRO, Michael Wingfield, stated in his speech: "IUFRO is proud to be one of the oldest international scientific organizations in the world. When IUFRO was founded in 1892 by forestry research 
institutes in Germany, Austria and Switzerland, these founding members shared the belief that research was in need of international engagement. Almost 125 years later, we can proudly say that this vision of the founding members has not only come true, but it has reached such a level, I am sure of this, which they could not dream of " (Wingfield, 2017).

Welcome speeches were also made by politicians and government officials of the federal (national) level: Hermann Onko Eikens, State Secretary of the Federal Ministry of Food and Agriculture, Berlin (Germany), Mark Chardonnens, Director of the Federal Office for the Environment, Berne (Switzerland), Gerhard Mannsberger, Head of Forestry, Federal Ministry of Agriculture and Forestry, Environmental Protection and Water Management, Vienna (Austria), Arno Briza, and Atashe for Agriculture, Embassy of France, Berlin (Germany).

The Congress, dedicated to the 125th anniversary of IUFRO, was intended to provide a platform for the exchange of scientific knowledge on forestry, related topics and varying scientific disciplines. A wide range of thematic sessions provided an opportunity to highlight innovative research and interdisciplinary research approaches to the study of forests, and focus on the transfer of scientific knowledge about critical global problems associated with forest processes on a national and international policy level.

The Congress focused considerably on communication issues. A series of "Science in Dialogue" meetings organized to bring scholars of forestry and related disciplines from all parts of the world, discussed national and international policies, as well as recognized responsible officials and important stakeholders. These sessions addressed a number of essential issues that have become the basis for the Congress's scientific program:

- How can the role of forests be improved in people's lives and quality of life, and what contribution can be made to forest regeneration?

- How can forests play a significant role in carbon sequestration and, at the same time, become more resilient to climate change?

- What is the importance of forests in newly created bioeconomics and how can we recognize their true value?

- How can biodiversity loss and the consequences of biological invasions be effectively addressed?

- How do trees, soil and water interact in forest ecosystems, and how can forests help improve fresh water quality?

In order to provide a basis for the dialogue sessions (listed below), the general theme - "Sustainable Development Challenges: Consequences for Forests and Forest Science" - has been identified, which has been discussed from a variety of perspectives and perspectives:

- science meets science (Part 1) - speeches by high-level international organizations and discussion with speakers - prominent researchers, representatives of international political organizations and ministers from a number of states;

- science meets science (Part 2) - panel discussion with respected scientists in the field of forestry and other related disciplines (agriculture, social sciences, etc.);

- Science meets with stakeholders - panel discussion with representatives of key stakeholder organizations;

- Science meets business - a networking event - communication with leading representatives of various forest enterprises, companies with a focus on forest education and qualifications required for the forest industry.
Special attention at the Congress was paid to the question of efficient communication with society, and the role of the forestry profession and science in society. A vivid manifestation of this discussion was during the session, "Communication with Einstein - about forest facts, sensations and fake news".

At the beginning of the session, in the short recorded video, the answers from the past were sounded. The actor who played the role of Albert Einstein on the question of the present as to how the forest is perceived and managed by a wide circle of society.

Answers of Einstein - his real quotations - became simultaneously thematic slogans of reports on effective communication with society: "It is harder to crack a prejudice than an atom: (A. Einstein) - "Why communicate effectively?" - Lintunen K. (Finland), Geshandtl I. (Austria), "In the middle of difficulty, lies opportunity" (A. Einstein) "How can science and academics play a significant role?" Hays J. (USA), Sands Y. (USA)), "Everything should be as simple as possible, but not simpler" (A. Einstein) - "How and why do we often misunderstand this?" - Lintunen K. (Finland), "If you can not explain it simply, you do not understand it well enough" (A. Enshtein) - "How do we work well, effectively?" - de Christopharo M. (Italy).

The Congress resolution outlined the IUFRO's task, namely how forest science in general and IUFRO, in particular, should focus on addressing global challenges and finding ways to implement them. The resolution especially emphasizes the importance of strengthening the scientific and political interface in order to ensure that future management of priority needs of interested parties would be more balanced and more definitive, and acceptable interdisciplinary solutions were formed on the basis of modern science.

It is noteworthy that Ukrainian scientists also took an active part in the work of the Congress on the occasion of the 125th anniversary of IUFRO. The delegation of Ukraine at the congress included representatives of such institutions:

- Ukrainian National Forestry University: Professor of the Department of Economics and Management of Forest Enterprises, Doctor of Economics A.M. Deyneka, Professor of the Department of Ecological Economics, Doctor of Economic Sciences I.P. Soloviy, Head of the Department of Forestry, Professor, Department of Forestry, Doctor of Agricultural Sciences V.V. Lavnyy, Head of the Department of Ecological Economics, Associate Professor, Candidate of Geographical Sciences I.A. Dubovich, Associate Professor of the Department of Ecological Economics, Candidate of Economic Sciences LL.I. Maxymiv, Assistant Professor of Forestry Department, Candidate of Agricultural sciences S.L. Kopiy, Junior Researcher, M.P. Melnykovych, ex-assistant to the Rector of the Ukrainian National Forestry University B.I. Kolisnyk;

- National University of Life and Environmental Sciences of Ukraine: Director of the Institute of Forestry and Landscape Management, Doctor of Agricultural Sciences, Professor P.I. Lakyda, Doctor of Economics, Professor A.I. Karpuk, Ph.D. in Agricultural Sciences, Associate Professor I.P. Lakyda;

- Ukrainian Scientific Research Institute of Forestry and Forest Melioration named after G.N. Vysotsky., Kharkiv: Leading Researcher, Doctor of Agricultural Sciences, Professor V.P. Pasternak.

The following papers were presented at the Congress from the National Forestry University of Ukraine (IUFRO 125th Anniversary Congress, 2017, Freiburg, Germany): 
- Ecological economics paradigm for sustaining forestry and people (T. Tunytsya, Y. Tunytsya);

- Close to nature forestry (Ukraine experience) (H. Krynytskyi, A. Dejneka, O. Krynytska, M. Chernjavskiy);

- Reimagining forest policy, institutions and instruments according to societal expectations the focus on Ukraine and beyond (I. Soloviy, M. Nijnik, A. Deyneka, M. Melnykovych);

- Current problems in cross-border cooperation of Ukraine and neighboring countries in the field of sustainable forest management (I. Dubovich);

- Building capacities for sustainability of local communities in marginalized rural areas: lessons learnt in the Ukraine's Carpathians and Scotland's uplands (M. Melnykovych, M. Nijnik, I. Soloviy, A. Nijnik);

- Assessing forest policy options through an improved understanding of the attitudes prevailing in forest-dependent communities and building resilience in the Ukraine's Carpathians (S. Kopiy, M. Nijnik, G. Krynytskyy, L. Kopiy, A. Nijnik);

- Prospects for restoration of degraded landscapes within the Yavoriv sulphur quarry (Ukraine) through woodland development (S. Kopiy, M. Nijnik, A. Nijnik, M. Kopiy);

- Identifying Green Energy Options for the Ukrainian Carpathians from a biophysical and socioeconomic perspective (Astrid Bjornsen Gurung, Irmi Seidl, Lyudmyla Maksymiv) (IUFRO Congress, 2017).

Two papers were presented from the National University of Life and Environmental Sciences of Ukraine:

- Improvement of information support for growth and productivity of forests as a precondition for risk resilient forest management (I. Lakyda, A. Shvidenko, R. Vasylyshyn);

- Economic and environmental challenges of climate change for forests of Eastern European part of Middle Latitude zone (P. Lakyda, A. Karpuk, I. Lakyda) (IUFRO Congress, 2017).

From the Ukrainian Research Institute of Forestry, Kharkiv a paper was presented on the subject "Vulnerability assessment of the main forest tree species due to climate change in Ukraine" (I. Buksha, M. Bondaruk, O. Tselishev, M. Buksha, T. Pyvovar, V. Pasternak) (IUFRO Congress, 2017).

The delegation of Ukraine became the most numerous in comparison with past Congresses of IUFRO, and its participation was very active: 7 oral presentations and presentation in the poster session; session management "Ecosystem services and the well-being of forest-dependent communities: enhancing social innovation and building resilience to global changes in remote rural areas"

(Chais: Prof. Maria Nyznyk, James Hatton Institute, UK and Junior Reasearcher Mariana Melnikovych, National Fo- restry University of Ukraine), which was attended by more than 70 participants; meetings with the head of the organizing committee Prof. Konstantin von Toefel and representatives of a number of partner institutions from Austria, Bulgaria, the United Kingdom, Germany, Romania, the United States, Switzerland, Sweden and others.

It should be noted that the papers presented by the Ukrainian scientists covered a wide range of topical issues of forestry science and forestry practices in an interdisciplinary context and were highly appreciated by Congressional participants.

Conclusion: The forest sector has changed radically throughout the history of IUFRO. These changes are related to such factors as globalization, governance reforms, and multi-sectoral relations, diversification of forest products and growth of public expectations in addressing social and environmental issues. Despite the fact that due to these transformations some new challenges have arisen, these changes have led to greater interdisciplinary collaboration in research and the sharing of new technologies, especially for information and communication purposes.

In order to find the answer to the challenges facing mankind and global ecosystems, present and future generations will have to make significant efforts to maintain vital sustainability and positive dynamics of forests. The IUFRO's long-term priorities for sustainability, responsibility and global cooperation require not only deep knowledge but also a strong moral sense. The analysis of the past 125 years, and in particular the work of the Anniversary Congress, testify that IUFRO possesses sufficient knowledge and a high ethical reserve, and therefore successfully pursues the search for answers to the complex challenges of the present and in the coming years.

\section{References}

Burley, J., Lee, D. K., Salleh, M. N., \& Seppälä, R. (2014). Research responses to major forestry and forest products challenges over the past quarter century. The international forestry review, 16(5), 15.

IUFRO Congress (2017). IUFRO 125th Anniversary Congress. Book of Abstracts. 18-22 September 2017, Freiburg, Germany. 725 p. Retrieved from: $\quad$ http://iufro2017.com/wpcontent/uploads/2017/11/IUFRO17_Abstract_Book.pdf

Johann, E., Buck, A., Burger, B., Kleine, M., Prüller, R., \& Wolfrum, G. (2017). 125 Years of IUFRO. History of the International Union of Forest Research Organizations 1892-2017. Vienna. 128 p.

Wingfield, M. (2017). Welcome Messages. Retrieved from: http://iufro2017.com/welcome-messages/\#wingfield

\section{І. П. Соловій, І. А. Дубовіч}

Національний лісотехнічний університет Украйни, м. Львів, Україна

\section{ЮВІЛЕЙНИЙ КОНГРЕС IUFRО: РЕЗУЛЬТАТИ ТА ПЕРСПЕКТИВИ РОЗВИТКУ МІЖНАРОДНОЇ СПІВПРАЦІ У ГАЛУЗІ ЛІСІВНИЧОЇ НАУКИ}

\footnotetext{
У вересні 2017 р. в м. Фрайбург (Німеччина) відбувся Ювілейний Конгрес, присвячений 125-ти річчю Міжнародної спілки лісових дослідницьких організацій (IUFRO). Розглянуто історію, проаналізовано тенденції розвитку міжнародної співпраці дослідників лісів і лісового господарства, яка підвищує ефективність досліджень. Звернено увагу не лише на питання співпраці IUFRO у сфері досліджень, а й на поширення наукових знань серед осіб, що приймають політичні, екологічні та економічні рішення. Розкрито особливості діяльності IUFRO, спрямованої на формулювання і впровадження лісової політики відповідно до вимог концепції сталого ведення лісового господарства. Акцентовано увагу на проблемах, які призвели до створення IUFRO, а також на їі різнобічній (організаційній, видавничій, просвітницькій та ін.) діяльності. Доведено, що завдяки діяльності IUFRO досягнуто значних результатів у поглибленні розуміння закономірностей функціонування лісових екосистем, виконання ними широкого спектру функцій і надання послуг екосистем, попередження численних деструктивних загроз, сутності багатоцільового лісокористування та методів сталого невиснажливого ведення
} 
лісового господарства. Проаналізовано тематику, результати, досягнення, окреслені рубежі і перспективи розвитку лісівничої науки. Узагальнено результати участі українських вчених у роботі Конгресу.

Ключові слова: IUFRO; Ювілейний Конгрес IUFRO; лісове господарство; сталий розвиток; міжнародна співпраця.

И. П. Соловий, И. А. Дубович

Национальный лесотехнический университет Украины, г. Львов, Украина

\section{ЮБИЛЕЙНЫЙ КОНГРЕСС IUFRO: РЕЗУЛЬТАТЫ И ПЕРСПЕКТИВЫ РАЗВИТИЯ МЕЖДУНАРОДНОГО СОТРУДНИЧЕСТВА В ОБЛАСТИ ЛЕСОВОДСТВЕННОЙ НАУКИ}

В сентябре 2017 в г. Фрайбург (Германия) состоялся Юбилейный Конгресс, посвященный 125-летию Международного союза лесных исследовательских организаций (IUFRO). Рассмотрена история, проанализированы тенденции развития международного сотрудничества исследователей лесов и лесного хозяйства, которое существенно повышает эффективность исследований. Обращено внимание не только на вопросы сотрудничества IUFRO в научной сфере, а и в сфере распространения научных знаний среди лиц, принимающих политические, экологические и экономические решения. Раскрыты особенности деятельности IUFRO, направленной на формулировку и внедрение лесной политики в соответствии с требованиями концепции устойчивого ведения лесного хозяйства. Акцентировано внимание на проблемы, которые привели к созданию IUFRO, а также определяют ее разностороннюю (организационную, издательскую, просветительскую и др.) деятельность. Доказано, что благодаря деятельности IUFRO были достигнуты значительные результаты в углублении понимания закономерностей функционирования лесных экосистем, выполнение ими широкого круга функций и предоставления услуг экосистем, предупреждения многочисленных деструктивных угроз, сущности многоцелевого лесопользования и методов устойчивого ведения лесного хозяйства. Проанализировано тематику, результаты, достижения, очерченные рубежи и перспективы развития лесоводственной науки. Обобщены результаты участия украинстких ученых в работе Конгресса.

Ключевые слова: IUFRO; Юбилейный Конгресс IUFRO; лесное хозяйство; устойчивое развитие; международное сотрудничество. 